Laczó, Ferenc. "Szücs, Teri, ed. 2015. Bevésett nevek. Konferenciakötet. Budapest: Eötvös Loránd

Tudományegyetem, ELTE. 418 pp." Hungarian Cultural Studies. e-Journal of the American Hungarian Educators Association, Volume 10 (2017) DOI: 10.5195/ahea.2017.287

\title{
Szücs, Teri, ed. 2015. Bevésett nevek. Konferenciakötet. Budapest: Eötvös Loránd Tudományegyetem, ELTE. 418 pp
}

\section{Reviewed by Ferenc Laczó*, Maastricht University}

In November 2014 the Eötvös Loránd Tudományegyetem, ELTE, the major university in Budapest, presented on its humanities campus a memorial of the university's students and staff who had fallen victim of World War II and the Holocaust. Entitled Bevésett nevek ['Engraved Names'] and made of a two-hundred meter long narrow bronze rod implanted into the bricks of two campus buildings, the memorial shows the names and biographical details of the university's one hundred ninety-eight identified victims. As Laura Csonka, one of the researchers involved in the project of documentation and remembrance, announced at the unveiling ceremony, this was an important first step which, albeit much belated, expresses the university's readiness to acknowledge and commemorate the tragedy that befell almost two hundred of its students and teachers during World War II and the Holocaust (36).

To mark the unveiling of the impressive memorial, a commemorative-scholarly conference was organized and held in mid-November of the same year. The conference included presentations by a host of reputed Hungarian scholars, although, somewhat surprisingly, only a few of them were historians. The majority of the participants addressed various aspects of Holocaust culture, commemoration practices with emphasis on contemporary memorials, and the pre-1945 past of the university. The conference proceedings were subsequently published as Bevésett nevek.

Konferenciakötet ['Engraved Names - Conference Proceedings'] (available at: http://emlekhely.btk.elte.hu/konferencia) along with another volume that documents the stages of planning and creating the memorial, entitled Bevésett nevek. Emlékek nélkül emlékezni ['Engraved Names - Remembering without Memories'].

The conference volume includes numerous engaging and at times subtle articles attesting to the rarely appreciated sophistication of Hungarian intellectual, aesthetic, and literary discourse of the Holocaust, as well as to the rather narrow empirical bases of Hungarian Holocaust research. Still, taken as a whole, the volume may substantially contribute to the further development of selfreflexive Holocaust memory culture in Hungary. Scholarly questions clearly predominate on the pages of the volume, yet they never overpower its commemorative agenda. A related strength of this volume is that its contributors largely refrain from topical political polemics, which, given just how controversial and stormy the seventieth anniversary of the Holocaust in Hungary turned out to be, must have been an obvious temptation to all those involved in the conference and the volume summing it up.

*f.laczo@maastrichtuniversity.nl

$($ (c) $)$ EY

ULIS D-Sonk
New articles in this journal are licensed under a Creative Commons Attribution 4.0 International License.

This journal is published by the University Library System of the University of Pittsburgh as part of its D-Scribe Digital Publishing Program and is cosponsored by the University of Pittsburgh Press 
Laczó, Ferenc. "Szücs, Teri, ed. 2015. Bevésett nevek. Konferenciakötet. Budapest: Eötvös Loránd

Tudományegyetem, ELTE. 418 pp." Hungarian Cultural Studies. e-Journal of the American Hungarian Educators Association, Volume 10 (2017) DOI: 10.5195/ahea.2017.287

As one of the main initiators of the memorial, Péter György, rightly highlights, memory work can play an essential role in strengthening the university community. György also asserts that a new consensus needs to be ambitioned to overcome the tendency toward outright politicization of remembrance (41). How memorials actually function and how the Holocaust should be memorialized are key issues in the eyes of the volume editor, Teri Szücs, as seen in her intriguing reflections on suffering, physicality and dignity. Szücs discusses how well-functioning memorials enable us to sharply experience the drama of our own physical presence as we relate to both the past and the present.

A melancholic counterpoint to Szücs's reflections - and, one is tempted to add, also to the ELTE Memorial - is provided by Hedvig Turai's article, which covers the main reasons behind the practical invisibility of the memorial to the March of the Living (held in Budapest annually since 2004). The predominant forms of cultural remembrance in Hungarian culture are deeply ambiguous and in some respects even paradoxical in that they enable a sharply polemical attitude to the recent past to coexist side-by-side with worrying degrees of indifference. Turai's analysis of the failed attempt at memorialization is therefore all the more welcome; at the same time, the volume as a whole might have done more to critically examine still other problematic aspects of contemporary processes of remembrance.

Besides further reflections on memorial spaces, semantics and functions, this volume also makes several contributions to an overdue examination of the university's history. Drawing on the Horthy era's daily press as well as on later memoirs, Zsolt K. Horváth's wide-ranging and subtle article approaches the physical and psychological terror exerted on and experienced by targeted members of the university. Employing anthropological theories on ritual acts and on symbolic exercise of power, K. Horváth aims at reconstructing the milieu and atmosphere of a university that served as a prime setting for power struggles and social conflicts rather than as a proper place for the pursuit of Bildung. Besides its other merits, this article offers an illuminating sketch of the highly controlled and conscious violence exercised by various bajtársi ['brother-in-arm'] associations at the university, such as the Csaba or Werböczy, and the rhetoric of self-defense with which they accompanied it.

In a similarly nuanced article, Anna Borgos discusses the political ideologies and societal values of the Horthy period and points at the interconnections between the regime's discriminatory intentions and practices toward both Jews and women. Borgos at first shows how, beyond the actual overlap between the two groups, there were also notable similarities in the government's fears expressed toward both (113). While her multilayered study sheds some light on the time's conservative-nationalist turn regarding women, it concludes that by the 1930s the stories of Jews and women at the central, Budapest-based university, then called Pázmány University, diverged as by then the rate of women students became stable whereas that of Jewish ones was drastically reduced as a result of increasingly radical anti-Semitic policies. By this time, Borgos notes, Jewish women were no longer excluded as women but rather as Jews, yet one way or another they were excluded from the country's higher education (127).

The most extended case-study in the volume is Géza Komoróczy's article entitled “Egyetem, zsidók, judaisztika. Mire emlékezünk?” ['University, Jews, Jewish Studies - What Do We Remember?'], which studies the history of anti-Semitism at the ELTE Humanities Faculty. Komoróczy, a leading scholar of Jewish history, reveals that already since 1919 multifaceted discrimination was enacted against Jewish students, including those aiming to earn double degrees at both the university and the Jewish Rabbinical Seminary. The author shows that during the first 
Laczó, Ferenc. "Szücs, Teri, ed. 2015. Bevésett nevek. Konferenciakötet. Budapest: Eötvös Loránd

Tudományegyetem, ELTE. 418 pp." Hungarian Cultural Studies. e-Journal of the American Hungarian Educators Association, Volume 10 (2017) DOI: 10.5195/ahea.2017.287

period of the Horthy era, the Faculty tended to implement even more severe anti-Semitic policies than did the Hungarian state. Komoróczy subsequently argues that in the later Horthy period the Faculty held on to its discriminatory agenda originally developed in the mid-1930s, thereby maintaining a modicum of decency without consciously choosing to do so. What makes this detailed and original study all the more important is that it also articulates a critique of the erected memorial. Komoróczy reveals that nearly ninety-five percent of the one hundred ninety-eight victims whose names appear on the new memorial were Hungarian Jews, and more than one-third of them were also students at the Rabbinical Seminary. Based on this striking finding, Komoróczy insists that the multilingual campus memorial ought to include Hebrew inscriptions as well.

Komoróczy concludes this well-documented, even if equally polemical, intervention claiming that although the memorial in its current design symbolically readmits the university's wartime citizens, still, the recognition that the large majority of the victims were Hungarian-Jewish persons has yet to be properly reflected and engraved on the monument.

József Takáts proposes in his contribution a more fruitful approach to remembrance than the existing ones. In his vision a new institution should be founded to foster historical cognition and learning which would, somewhat like a novel, employ multiple registers and perspectives thus pursuing the four goals of integration, decentralization, alleviation and solace. Revealingly, Takáts does not aim at a theoretical debate of these goals (something that, as he sarcastically remarks on, Hungarian intellectuals would prefer) and would instead prefer to first observe the actual social impact of the institution he proposes. Although he does not claim to have discovered the ultimate method of dealing with a painful and divisive past, still, he modestly suggests that his proposal, if realized, might lead to meaningful processes in the right direction.

In contrast to Takáts' pragmatism, Anna Lujza Szász and Máté Zombory's critical overview of contemporary discourses of Holocaust memory entertains rather abstract and even generalized ideas. Szász and Zombory address several key debates of recent years, such as the transnationalization and globalization of Holocaust memory, the problem of localization and power relations in the European context, and the limits of representation. They are right in insisting that official discourses on Holocaust memory tend to be closely connected to specific normative and retrospective expectations and therefore remain insufficiently sensitive to conceptual histories and contemporary power relations. However, their article barely details any such normative expectations and their implications, nor does it offer any comparisons of discursive agents. Nonetheless, this article's multifaceted and critical engagement with current transnational scholarly discussions could make it an ideal opening of a debate, which is sourly missing in present-day Hungarian Holocaust discourse, on the merits and shortcomings of contemporary Holocaust culture.

Further highlights of the volume include Noémi Herczog's surprising reflections on the taboo of laughter and what she calls the genre of Holocaust comedy, and Dávid Szolláth's discussion of the functioning and results of historical relativism and playfulness in László Márton's 1999 novel Árnyas föutca ['Shadowy Main Street']. Herczog argues that the selfjustification of Holocaust tragedies may be morally laudable but such tragedies often disappoint us in the aesthetic-psychological sense, whereas a sense of the tragic can develop while we view seemingly comical scenes. In other words, satire could turn out to be a more useful mode than pathos; laughter, she asserts, can be a fruitful reaction if directed not at the tragic events themselves but at the inadequacies of their current treatment. Dávid Szolláth in turn tackles moot questions in historical epistemology, literary theory and ethical thought, inquiring, more 
Laczó, Ferenc. "Szücs, Teri, ed. 2015. Bevésett nevek. Konferenciakötet. Budapest: Eötvös Loránd

Tudományegyetem, ELTE. 418 pp." Hungarian Cultural Studies. e-Journal of the American Hungarian Educators Association, Volume 10 (2017) DOI: 10.5195/ahea.2017.287

concretely, into what Márton's self-reflexive, postmodern, intertextual prose accomplishes when dealing with the traumatic past. Szolláth concludes that Márton's Árnyas föutca may appear to reject piety but it actually displays an ironic (di)stance toward its own narrative strategy.

Perhaps less counter-intuitive yet equally substantial is József Havasréti's exploration of Antal Szerb's identity discourse as he compares and at times contrasts Szerb's intimate reflections with his public pronouncements. Havasréti also discusses how and with what exact consequences Szerb's manner of dealing with identity issues by rejecting dilemmas of origin in favor of universal humanism disintegrated under the pressure of the radicalized anti-Semitic discourse of his environment. The three articles by Herczog, Szolláth, and Havasréti are well-focused, ingenious works that fruitfully challenge present-day clichéd commemoration rhetorics. However, with the partial exception of Szolláth's work, they largely refrain from broader contextualizations of their intriguing topics and source materials.

Last but not least, while the primary focus of Bevésett nevek is clearly on Hungarian materials and no comparative ambitions are pursued on its pages, several articles in it do tackle extra-Hungarian subjects, such as contemporary Polish movies on historically sensitive issues (Balázs Varga); Anne Frank's literary strategies and qualities (Judit Gera); the suppressed history of American eugenics (Zsófia Bán); or Charlotte Delbo's representation of the murdered and the surviving members of the French resistance (Anna Marczisovszky). Seen as a whole, Bevésett nevek. Konferenciakötet amounts to a multifaceted, rich and challenging collection. It constitutes a significant accomplishment that hopefully will prove to be a promising beginning too. 